\section{Diet and Nutritional Status of Ameridians: A Review of the Literature}

Este trabalho revê e avalia os dados disponiveis sobre a alimentação e estado nutricional de amerindios que habitam as florestas pluviais tropicais da Amazônia. A alimentação da maioria dos ameríndios está baseada na mandioca e na banana, enquanto que peixes, animais silvestres e invertebrados são responsáveis por proteinas de alta qualidade. Só é conliecida a composição da alimentação amerindia de alguns grupos. Nestes, $o$ consumo alimentar das familias e dos adultos parece ser adequado em termos de calorias e proteinas. Contudo, a baixa densidade calórica da alimentação, baseada na mandioca e na banana, sugere que esta não $e ́$ concentrada o bastante para as crianças. Dados antropométricos de inúmeros grupos encontram-se disponiveis. Os adultos são de baixa estatura, porém o seu estado nutricional, avaliado en termos de peso/altura, é geralmente bom. As crianças são pequenas para sua idade e, em certos grupos, mais de 10\% seriam classificadas como subnutridas, com base no critério peso/altura e/ou em sinais clínicos.

\title{
INTRODUCTION
}

Amazonia is home to a number of Amerindian groups who make a living by some combination of swidden horticulture, hunting, fishing and foraging. These populations have been disappearing at a rapid rate since the turn of the century as areas of forest and cerrado have been developed (Ribeiro, 1967), but there are still a number of Amerindian groups that are self-sufficient, or almost self-sufficient, in food production, and have diets that appear 
to be traditional. The purpose of this paper is to review what is known of the diet and nutritional status of these groups.

Ideally we would like to be able to define Amerindian diets in terms of ecological variables, the characteristics of food resources, patterns of food selection and use, and the implications that these have for dietary adequacy, nutritional status and health. We would also like to understand how these change with contact and assimilation into Western society. However, much of what is known about diet in Amazonia is anecdotal. This kind of information is useful in providing a preliminary description of the diet, but provides little on which to judge the adequacy of the diet or potential nutritional problems. There is somewhat better information available on nutritional status, especially anthropometric indicators of nutritional status, but the interpretation of these indices is not straight forward because they are sensitive to a variety of environmental variables, as well as diet.

Amazonia is used here following Denevan (1976) to include the area of South America east of the Andes and north of the Tropic of Capricorn. It thus includes all of the tropical lowlands and interior plateaus east of the Andes. Climatically most of the area is warm and relatively humid. Rainfall is highest in the western portion around the equator. In this area rainfall is between 2500 and 3500 $\mathrm{mm} / \mathrm{yr}$ with no month receiving less than $100 \mathrm{~mm}$. There is no real "dry" season, but there is typically a period of 2-3 months of relatively low rainfall. Moving east rainfall decreases to $1000-2000 \mathrm{~mm} / \mathrm{yr}$ and becomes more seasonal. In Central Brazil there is a dry season of 3-4 months (Prance, 1978).

For descriptive purposes it is useful to divide Amazonia into three regions: northern, western and southern peripheral Amazonia. These distinctions conform to Fittkau's ecological subregions (Herrera et al., 1978). A fourth region, central Amazonia, which includes the floodplain of the Amazon River itself, is not considered here since its inhabitants were not known ethnographically.

The Amerindian groups for which there is some information on diet are described below. At the time they were observed almost all had subsistence systems based on 
swidden horticulture, hunting, fishing and gathering, and except for the Xavánte, inhabited tropical forest environments. The dates during which they were observed are only a rough guide to their degree of acculturation, since contact and assimilation have proceeded at very different paces in different parts of Amazonia.

\section{General characteristics of Amazonian diets}

In northern peripheral Amazonia the groups inhabiting low lying forested regions along rivers shared a diet based on bitter cassava (Manihot esculenta) prepared as bread (casabe or beiju), or meal (fariña or mañoco), and fish.

Boza and Baumgartner (1962) studied Piapocos, Piaroas, and Guahibos living along the upper Orinoco and Venturari Rivers in Venezuela in 1952. casabe was the most frequently consumed food, followed in rank order by fish, yucuta (fariña and water), meat, fruits (all types), and maize. Of the fruits consumed, palm fruits were the most important in the diet. In addition to game animals, they also reported the use of a variety of small fauna including frogs, snakes, bats and insects.

The Tiriyó and Wayana in the Guianas were studied by Glanville and Geerdink (1970) in the mid 1960's shortly after their first contact with missionaries. They appeared to have a very similar diet to that of the Piapocos, Piaroas and Guahibos. More recent work by Dufour (1983) with Tatuyo-Tukananos in the Vaupes region of Colombia in the late 1970's, and by Holmes (1981) with the Kuripáko in the San Carlos de Rio Negro region of Venezuela in the early 1980 's, also indicates similar diets based on casabe and fish.

The Yanomámi who inhabit interior mountainous rain forest regions along the Venezuelan-Brazilian border away from the major rivers, have a somewhat different diet. According to ethnographers, plantain/banana were the dietary staples, and game the principal source of animal protein (Lizot, 1977; Smole, 1976). Until very recently they were one of the groups with the least contact with westerners.

In western peripheral Amazonia there are a number of groups inhabiting the rain forests on the lower slopes of 
the Andes (montaña) and in the adjacent lowlands. Information on diet is available for the Aguaruna (Berlin and Markell, 1977) and Siona-Secoya (Vickers, 1989) for the mid 1970's, and from the Shipibo from the early 1980's (Behrens, 1984; Hodges and Dufour, 1991). These groups share a broadly similar diet based on sweet cassava, plantains and bananas, and fish and game. In this region much of the cassava is consumed as a premasticated, slightly fermented drink (Behrens, 1984; Berlin and Markell, 1977; Dricot-D'Ans and Dricot, 1978; Ross, 1976; Vickers, 1989).

For Amerindians in southern peripheral Amazonia there is no detailed information on diet, but there appears to be more diversity in the foods used. Coimbra (1985) described the Suruí of the Aripuanã Park in 1979-83 as relying on maize as a dietary staple and game as the principal source of animal protein. For the Menkrangnoti-Kayapó (Central Brazil, state of Para) described by Werner (1983) in 1976-77 food staples were: sweet potatoes, bitter cassava, plantain and maize in that order. Meat, from a variety of game animals, was the principal source of animal protein. Although the Menkrangnoti trekked several months of year, they did not consume much wild vegetable food, with the exception of Brazil nuts (Bertholetia excelsia). For Amerindians in the Alto Xingu area the staple foods were reported to be bitter cassava, prepared as beiju and fish. These groups reportedly used a variety of "wild" fruits and nuts, as well as honey (Eveleth et a1., 1974; Fagundes-Neto et al., 1981). Their diet appears to be similar to that of the riverine-oriented groups in northern peripheral Amazonia.

The Xavánte live further south and east in an area of cerrado vegetation on the Central Brazilian Plateau. Maybury-Lewis reported that in 1955-58 they were living in the cerrado and swiddening in gallery forest. They trekked all year except for about the three months they devoted to horticulture. Their diet was based on wild roots, palmito, wild nuts, fruits and game (Maybury-Lewis, 1967: 43-44). The toots functioned as the carbohydrate staple, but whether they were actually "wild" rather than cultivated is open to question. In the swiddens the Xavante grew maize, beans and pumpkins, and these foods were 
important in the diet right after the harvest. This description agrees with that of Freitas and Oliveira (1955) for the Nação Xavánte in 1954.

The more recent work of Flowers (1983) with the Xavánte at Pimental Barbosa in 1976-77 indicates that they have adopted upland rice as a dietary staple, and were trekking only about two weeks of the year. They collected "wild" roots only occasionally, but did collect large quantities of palmito, palm nuts and other fruits. Palmito was eaten fresh, or dried and pounded into a flour which was boiled into a thick soup. Game was more important in the diet than fish. Flowers (1983) reported that they sold some of their rice, but included few purchased foods in the diet.

\section{Composition of Diets}

More detailed information on diet composition is available for five groups: Aguaruna, Shipibo, Siona-Secoya, Tukánoans and Yanomámi. Energy and protein intake in these diets is summarized in Figure I. All of the data is at household or village level and restricted to one season of the year. In four of these diets between 76 and $87 \%$ of the energy is derived from two staples, cassava and plantains/bananas. After the starchy staple, fish and game are the second most important source of food energy.

Although a wide variety of crops were cultivated by each of these groups, other cultigens were relatively minor components of the diet, providing between 0 and $9 \%$ of all food energy. The Siona-Secoya diet described by Vickers (1989) shows a slightly different pattern: cassava and plantain provide $53 \%$ of the food energy and other cultigens provide $19 \%$. Almost all of the latter was derived from peach palm fruit (Bactris gasipaes), which is only available seasonally. The composition of the Siona-Secoya diet reported by Bénéfice et al. (1989) is more similar to that of other groups with about $72 \%$ of the food energy coming from the staples, cassava and plantains/bananas.

Uncultivated plant foods contributed between 0 and $7 \%$ of all food energy. The Yanomámi, the least acculturated group, relied more heavily on these foods than did the other four groups. Palm fruits were the most important 
wild vegetable foods. Boza and Baumgartner (1962) present food frequency data for the Piaroas, Guahibos and Piapocos which also suggests greater reliance on uncultivated plant foods than was found in the Aguaruna, Shipibo, Siona-Secoya and Tukánoans.

More than half of all the protein in these diets is coming from fish and game (Figure $\mathrm{D}$ ), so the protein quality of the diets is high. With the exception of Yanomámi, fish were the most important source of animal protein, and that seems to be true for a number of other groups as well. A wide variety of game animals are consumed, but small mammals, such as rodents are usually the most important. These are of course the more abundant in the ecosystem. The category "other" includes insects and small vertebrates, like frogs. These sources of animal protein are frequently mentioned by observers, and probably more important than most of the available data indicate (Dufour, 1987).

\section{FIGURE I-A}

Energy and Protein Composition of Five Amerindian Diets

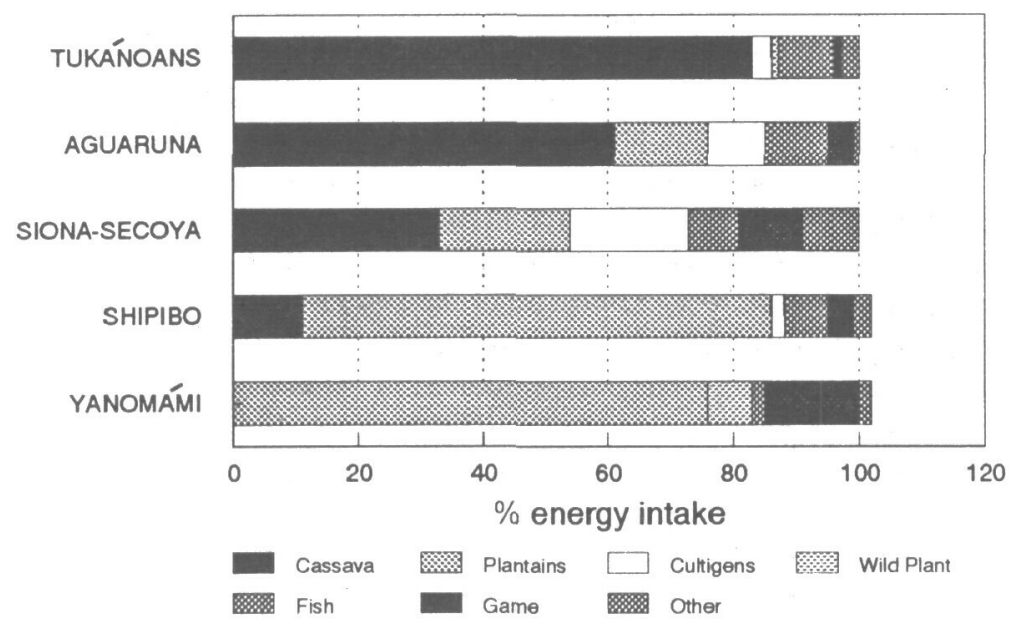


FIGURE I-B

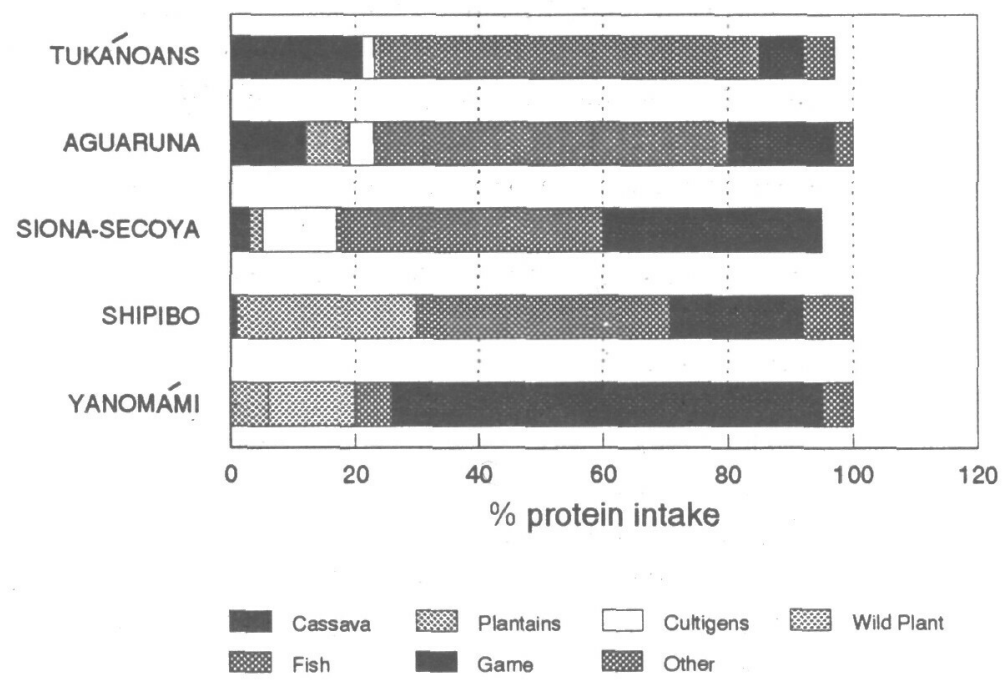

Aguaruna data from Berlin and Berlin (1977) based on 30-day weighed records for 5 households. Records were kept by the subjects. "Cultigens" were primarily fruit; "other" is a mixed category which included roots and tubers, seeds and other plant parts, as well as crustaceans, frogs and insects. Approximately a third of the energy derived from cassava was in the form of cassava beer or masato. Shipibo dietary data calculated from Behrens (1986) from weighed intake records for 17 households visited on 25 different days. "Cultigens" included rice, potatoes, squash and beans; "other" included domesticated pork and chicken. Values do not include fruits or wild plant food, which Behrens estimated to be less than $1 \%$ of the tctal weight of all foods consumed. Siona-Secoya data from Vickers (1989) for 3-day weighed records for four adults and one child. Cultigens included peach palm (16\% of total food energy), papaya and sugar cane; "other" included rice and sugar. Tukánoan data from Dufour (1983) from 3-day weighed records for four households. "Other" is primarily insects. Yanomámi data from Lizot (1977) based on 42 days of "observation" in one village and 28 days in another. Method used unclear. "Other" includes insects and crustaceans. 
In terms of macronutrients Amerindian diets appear to be high in carbohydrates and quite low in fat. In the Tukánoan diet approximately $81 \%$ of the food energy is derived from carbohydrate, $11 \%$ from protein $(8 \%$ from animal protein), and 8\% from fat (Dufour, 1984b). The Siona-Secoya diet is similar, $75 \%$ carbohydrate, $14 \%$ protein and 11\% fat (Vickers, 1989:149). The level of energy derived from protein in these diets is not unusual in self-selected diets (FAO/WHO, 1973:22), but the percent of energy derived from fat is very low.

\section{Cassava as a staple}

The distinction between bitter and sweet cassava made ethnographically is usually in terms of informant/observer preceptions of how toxic the roots are, and/or how they are prepared. "Sweet" cultivars have roots which can be eaten simply roasted in the coals, or peeled and boiled. Roots of "bitter" cultivars, on the other hand, require more elaborate processing to remove their bitter taste and make them safe to eat. Roots of these varieties are typically prepared as casabe, or fariña. Sweet cassava can also be prepared casabe or fariña, so that the presence of these two products in the diet does not necessarily mean that the roots being used are bitter varieties. Botanically the distinction between bitter and sweet cassava is usually in terms of cyanide content; roots with a cyanide content of $100 \mathrm{ppm}$ or more are considered high-cyanide or "bitter".

The cyanide content of cassava is a potential health hazard, and indecd some rescarchers consider the bitter cultivars unsuitable as human food (Gomez et al., 1984). Cyanide toxicity associated with cassava consumption has been linked to a number of health problems in Africa, including acute toxicity, goiter and spastic paraparesis (Nestel and MacIntyre, 1973; Ermans et al., 1980; Osuntokun, 1981; Rosling, 1987). Cassava consumption has not, however, been associated with health problems in Amazonia, even though some groups rely on cassava for a large percentage of their dietary energy, and use unusually bitter varictics (Dufour, 1988). This probably reflects the adequacy of traditional food processing 
systems in reducing cyanide to physiologically tolerable levels (Dufour, 1989), as well as the general adequacy of their diet in providing substrates for metabolic detoxication of residual cyanide. None the less, the health significance of the residual cyanide in Amerindian diets remains to be clarified.

\section{Seasonal variations in diet and wild food use}

Seasonal variations in diet have not been well studied. Seasonal variations in total food supply are probably less important in rain forest regions than in the drier tropics because the dietary staples, cassava and plantain, are under continuous cultivation, and harvested throughout the year. However, the intake of wild vegetable and animal foods would be expected to vary during the year in accordance with their availability. The consumption of some cultigens would also be expected to vary seasonally. The high intake of peach palm fruit (Bactris gasipaes) in the Siona-Secoya diet is a good example of this.

In the Tukánoan diet, cassava and other cultigens did not show much seasonal variation (Figure II), but animal foods and uncultivated plant foods did. $\Gamma_{\text {ish was more }}$ important in the diet in the November-January period, the dry season, the time of the year when fishing is most productive. Uncultivated plant foods were more important in the rainy season, a time of the year when many trees come into fruit. Some insects are especially abundant during this time of the year as well.

Most of the wild plant foods collected were nuts and seeds of large trees, and palm fruits. These are generally good sources of fats and protein. In one year, 1977, impressive amounts of two seeds, Erisma Japura and Monopteryx angustifolia, were collected (Dufour and Zarucchi, 1979). It is worth noting however, that both of these were from trees that only fruit on alternate years, and the next year neither were available. Both of these seeds were considered toxic and detoxified for consumption. The presence of toxins in the wild plant food component of the diet is an area of rescarch that deserves more attention. 


\section{FIGURE II}

Seasonal Variation in the Diet of Tukánoan Adult Males and Females. See Table 3 for Sample Sizes

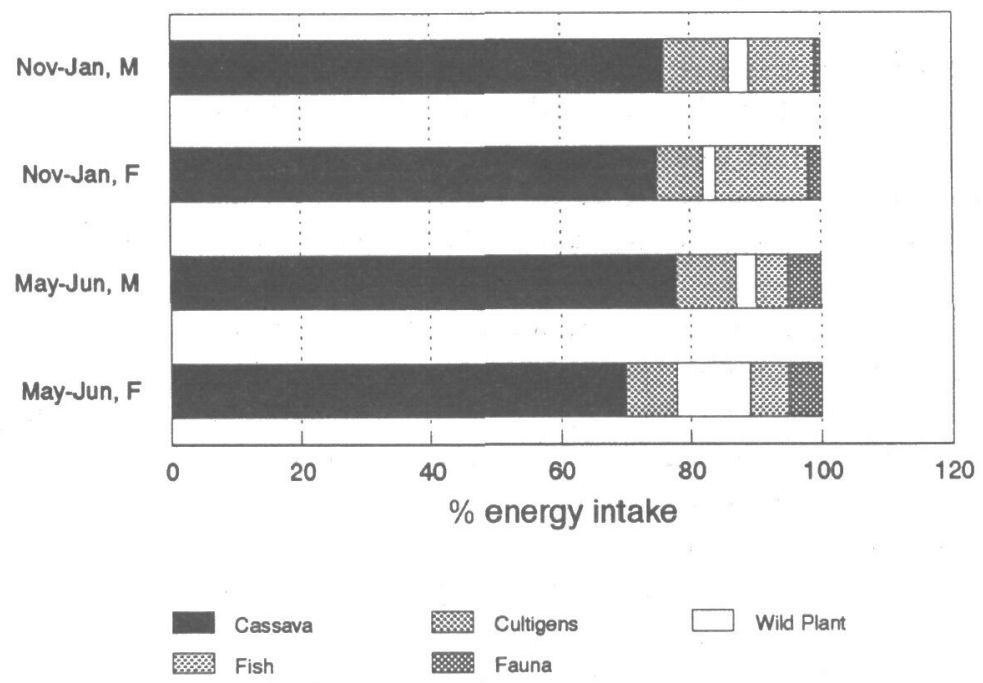

The relatively limited contribution of wild plant foods to Amerindian diets may be simply an artifact of the methods used to collect the dietary data, or the season of the year the data were collected, or the age of the settlement, or some combination of these three factors. First, methods that do not account for foods eaten away from the settlement tend to under report both wild plant foods and small fauna. Second, for the horticultural groups discussed here, the most important wild plant foods appear to be tree fruits, which are highly seasonal in availability, rather than starch storage organs such as palm heart, which should be available all year long. Since almost all of the data 
the year, it is likely that wild plant use was underreported. Third, some groups rely more heavily on wild plant foods at new settlements when their gardens are young and not in full production (Hill and Kaplan, 1990; Vickers, personal communication).

\section{Age and sex differences in diet and food intake}

There is little quantitative data on age and sex differences in diet among Amerindians, but ethnographic information suggests they may be important. There are a number of reports of food restriction during illness and life cycle events such as child birth. Further, in some groups, such as Tukánoans and Mehináku (Central Brazil), there are prolonged initiation rites during adolescence which are associated with severely restricted diets (Hugh-Jones, 1979; Gregor, 1985). In the case of the Mehináku the appearance of neurological disorders in young male initiates has been associated with the ingestion of certain wild plants during the period of seclusion (Gregor, 1985:148).

In the Tukánoan data sex differences in the diets of adults are not very great. The most striking is the greater use of wild vegetable foods by females in the May-June period. This suggests that exposure to toxins and other secondary compounds in the wild plant component of the diet may vary between the sexes.

The diets of children have not been investigated, but they may differ in important ways from those of adults.

\section{ADEQUACY OF AMERINDIAN DIETS}

The adequacy of indigenous diets is difficult to judge. Basically there are three types of criteria which can be used to evaluate the adequacy of a diet. First, energy and nutrient intake of a group of individuals in relationship to a standard. The most useful measurements are those of individuals of known sex, age, body weight and activity level carried out over a number of days during the annual cycle. Second, a measure of the adequacy of energy intake in relationship to energy expenditure. Third, indicators of biological status, such as anthropometric indices and clinical signs. 
Food intake in relationship to a standard

In terms of the first of these measures, food intake in relationship to a standard, there is very little data available. Household level food intake data for Aguaruna (Berlin and Markell, 1977), Siona-Secoya (Bénéfice et al., 1989), and Tukánoans (Dufour, 1983) suggest that intakes of energy and protein were adequate, but this is quite a crude measurement.

Results of a weighed food intake survey of Tukanoan adults in 1977-78 are shown in Table I. Mean energy intakes were $100 \%$ or more of the FAO/WHO (1973) recommendations for moderately active adults of corresponding body weight. For Tukánoans, energy intakes also appeared adequate in comparison to estimates of energy expenditure (Dufour, 1984a). Mean protein intakes were above the FAO/WHO (1973) safe level for both men and women. There was, however, considerable day to day variation in intake, due to the fluctuations in availability of wild fauna. Seasonal differences in protein intake were also greater than in total energy intake.

\section{TABLE I}

Mean (SD) Daily Energy and Protein Intakes, Percent FAO/WHO (1973) Recommendations, and Mean Daily Energy Expenditure of Tukánoan Adults by Sex and Season

\begin{tabular}{lcccccc}
\hline & \multicolumn{2}{c}{ ENERGY } & \multicolumn{2}{c}{ PROTEIN } & EE \\
& Kcal & \% FAO & 8 & \% FAO & Kcal \\
\hline Males & & & & & \\
Nov-Jan ( $n=27)$ & $3335 \pm 630$ & 113 & $96 \pm 74$ & 218 & $2806 \pm 382$ \\
May-June $(n=10)$ & $3017 \pm 844$ & 100 & $70 \pm 32$ & 152 & $2956 \pm 605$ \\
Females & & & & & \\
Nov-Jan ( $n=30)$ & $2413 \pm 592$ & 106 & $80 \pm 65$ & 200 & $2133 \pm 272$ \\
May-June $(n=13)$ & $2396 \pm 757$ & 123 & $65 \pm 37$ & 176 & $2051 \pm 248$ \\
\hline \hline
\end{tabular}

* $\mathbf{N}$ is the number of person-days. Weighed diet records were kept for 3 consecutive days for 9 males and 10 females in November-January (1977-1978), the dry season, and 1 day for 10 males and 13 fenules in May-June (1978), rainy season. Adequacy of protein intakes is based on the assumption that the diet has a protein quality of at least $70 \%$ relative to milk or éggs. 
Protein intakes estimated from creatine excretion were adequate for Tiriyó and Wayána adults and children (Glanville and Geerdink, 1970). This is the only data on dietary intake available for children.

There is no minimal $s$ andard for fat intake, but it is generally assumed that diets in which fat contributes $<15 \%$ of calories are not concentrated enough for young children (Wheeler, 1980). If the percentages of fat in the Tukánoan and Siona-Secoya diets ( 8 and $11 \%$ respectively) are representative, Amerindian diets have very low energy density, and the sheer volume of food required to meet energy needs is a potential constraint for children. The problem of food volume is most acute in western peripheral Amazonia because a high proportion of the food energy is in the form of cassava beer or banana gruels. The high bulk of the Aguaruna diet was pointed out by Berlin and Markell (1977).

The adequacy of other nutrients in Amerindian diets has been reported for Aguaruna and Siona-Secoya households. Aguaruna diets were adequate in calcium, phosphorus, iron, vitamins $A$ and $C$, thiamin, riboflavin and niacin (Berlin and Markell, 1977). Siona-Secoya diets were adequate in all of those same nutrients except vitamins $A$ and tiboflavin (Bénéfice et al., 1989).

\section{Anthropometric indicators of nutritional status}

Anthropometric indices of nutritional status for the groups considered here are summarized in Table II. In terms of weight-for-height, a measure of thinness and hence present nutritional status (Waterlow et al., 1977), most children and adults are within the normal range. The highest percentage of thinness is among the Aguaruna and Shipibo, groups in the montaña region. There is less data available for height-for-age, an indicator of linear growth over time (Waterlow, 1977). However, children in the two of the three groups for which there is data, Curripacos and Tukananos, show high frequencies of stunting. In Shipibo infants and young children deficits in linear growth in comparison to reference values begin between 3 and 6 months of age and continue through 36 months (Hodge and Dufour, 1991). Given the short stature of the adults in 
all of these groups, stunting in childhood is probably common. Stunting is considered indicative of long term nutritional inadequacy, and/or generally poor environmental conditions, especially those in which chronic or repeated infections are prevalent (WHO, 1986). Hence it is a nonspecific indicator of the general quality of life.

\section{TABLE II}

Anthropometric Indices of Nutritional Status for Selected Amerindians, Sexes Combined. Percent of Individuals Less than $80 \%$ Standard" Weight-for-Height (WT/HT) and/or Less than 90\% Standard Height-for-Age (HT/AGE)

\begin{tabular}{llrrc}
\hline \hline Group (Date) $^{* *}$ & Age, yrs & \multicolumn{1}{c}{$\mathrm{n}$} & WT/HT & HT/AGE \\
\hline PRE-SCHOOL CHILDREN & & & & \\
Aguaruna (1972-75) & $1-5$ & 35 & 35 & - \\
Kuripáko (1980-83) & $0-5.9$ & 34 & $0 @$ & 32 \\
Kayapó (1970-76) & $0-5.9$ & 87 & - & 16 \\
Shipibo & $<10$ & 43 & 14 & - \\
Tukánoans (1976-87) & $2-5.9$ & 120 & $0 @$ & 56 \\
Yanomámi (1982) & $?$ & 93 & $1 @$ & - \\
Xingu Tribes (1974-76) & $0-5$ & 175 & $<1$ & - \\
SCHOOL CHILDREN & & & & \\
Aguaruna (1972-75) & $6-19$ & 32 & 12 & - \\
Kuripáko (1980-83) & $6-17$ & 52 & $0 @$ & - \\
Tukánoans (1976-87) & $6-19$ & 481 & $<1$ & - \\
Yanomámi (1982) & $?$ & 102 & $2 @$ & - \\
ADULTS & & & & \\
Aguaruna (1972-75) & $20+$ & 50 & 10 & NA \\
Kuripáko (1980-83) & $18+$ & 47 & $0 @$ & NA \\
Tukánoans (1976-87) & $20+\mathrm{M}$ & 205 & $0 @$ & NA \\
\hline \hline
\end{tabular}

- Harvard standards as quoted by Jelliffe (1966). Age grouped as recomniended by Waterlow et al. (1977) when possible; no age data available for Yanomámi. Height for age is not applicable for adults (NA). Absence of data indicated by dash (-).

* References are as follows: Aguaruna (Berlin and Markell, 1977); Kuripáko includes Anerindians in San Carlos de Rio Negro and surromending villages (Holnues, 1981); Kayapó includes Xikrin and Menkrangnoth́ data read from growth charts in Black et al. (1977); Shipibo (Behrens, 1984); Tukánoan dara include Kubéu, Tukáno, Tatuyo, Karapanã, Barasána, Desána groups living in the Vaupes region of Colombia on Cuduyari, Qnereri, Alto Papuri, Paca Rivers (Dufour, n.d.); Yanomámi data read from figure in Holnes (1985: 250); Xingu tribes include Kamayurás, Ametis, Waurá, Yawallapitís, Mehinakús, Kuikúru, Kalapálo, Matipú-Nafukwá, Trumáis (Fagundes-Neto et al., 1981). 
The lack of dietary intake data for children makes it difficult to estimate the extent to which nutritional variables are responsible for slow growth. The possibility of chronic or recurrent food deficits in children's diets resulting from fluctuations in household food supplies, and/or inequitable food distribution within the household cannot be ruled out. Further, the high bulk, low caloric density of Amazonian diets may make it difficult for young children to meet their dietary needs when food is available, or to catch up after a period of deficit.

There is also ample evidence of chronic and repeated infections among Amerindian children. Holmes (1984) demonstrated the negative impact of measles on nutritional status in the San Carlos area. Malaria was endemic among the Alto Xingu groups (Fagundes-Neto et al., 1981), Kayapó (Ayres and Salzano, 1972), Tiriyó and Wayána (Glanville and Geerdink, 1970), and malarial infections have been associated with faltering growth (McGregor, 1982). Intestinal parasitism is common (Larrick et al., 1979; Berlin and Markell, 1977; Holmes, 1984; Bénéfice et al., 1989), but its impact on nutritional status in not entirely clear. Holmes (1984) found no relationship between weight-for-height and worm burden in San Carlos children, but other studies have shown that deworming enhances linear growth (Evans et al., 1985). There are also a number of reports of mild, but probably chronic, infections which could depress growth in children. Examples of these are eye disease among the Tiriyó and Wayána (Glanville and Geerdink, 1970), and skin diseases among the Kayapó (Ayres and Salzano, 1972) and the groups studied by Boza and Baumgartner (1962), and oral infections: 'iong Tukánoans and San Carlos childern (Holmes, 1981).

Climatic conditions themselves, via their effect on thermoregulation, are an additional factor which may also contribute to the short stature seen. The shortest human groups in both South America and Africa are found in areas of tropical rain forest (Hicrnaux and Froment, 1976; Stinson, 1990). 


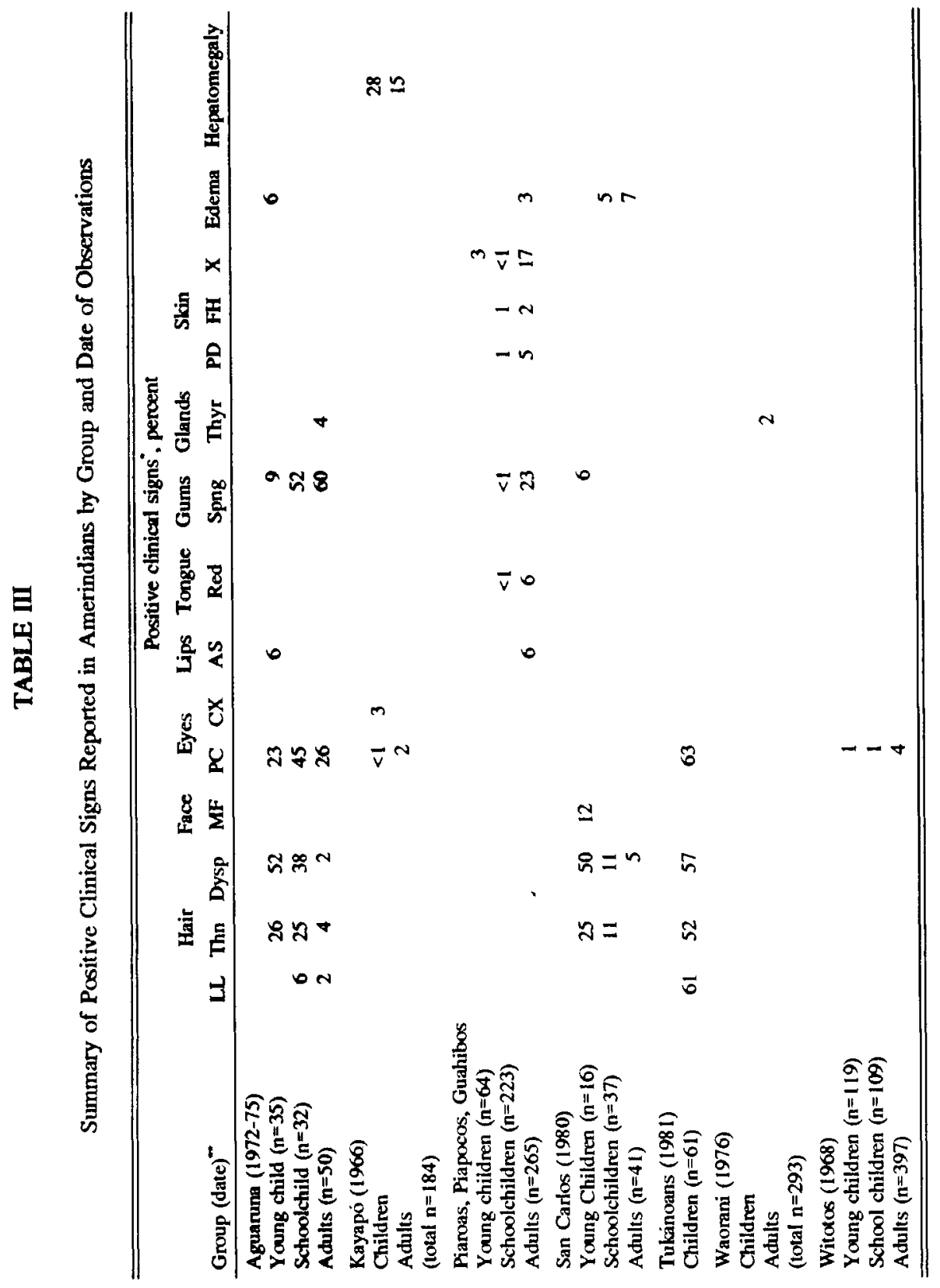


Includes signs listed in Group I by Jelliffe (1966): for the hair, lack of luster (LL), thinness and sparseness (Thn) and dyspigmentation (dysp); moon-face; for the eyes, pale conjunctiva (PC) and corneal xerosis (CX); for lips, angular stomatitis (AS); for the tongue, abnormally red (Red) and edema (E); for the gums, spongy, bleeding gums (Spng); thyroid gland enlargement (Thyr), for the skin, pellagrous dermatosis (PD), follicular byperkeratosis (FH) and xemosis (X); edema; hepatomegaly.

- References are as follows: Aguaruna (Berlin and Markell, 1977); Kayapó (Ayres and Salzano, 1972); Piaroas $(\mathrm{n}=217)$, Guahibos (n=188), Cuibas (n=34), and Piapocos (n=13) (Bosa and Baumgarmer, 1962); San Carlos area (Holmes, 1981); Tukinoans (Ortiz, 1981); Woorani (Larrick et al., 1979); Witotos (Gomez, 1968).

\section{Clinical signs}

The number of cases of what investigators have called "malnutrition" is very low: 3 cases in 184 Kayapó (Ayres and Salzano, 1972); $<5 \%$ of 293 Waorani (Larrick et al., 1979); 1 case in 112 Aguaruna (Berlin and Markell, 1977); 0 cases in 222 Siona-Secoya (Bénéfice et al.,1989). More common in the literature are descriptions of the excellent health of Amerindians, but these are typically with reference to adults, and usually males.

Clinical signs of undernutrition related to the condition of the hair (sparseness, pluckability, discoloration) have been reported for Aguaruna, Tukánoan and San Carlos children (Table III). The presence of these signs is consistent with anthropometric indicators of undernutrition in these groups. There is little evidence of specific nutrient deficiencies. The only goiter reported was for the Xavante, although iodine deficiency without goiter has been reported for the Yanomámi (Riviere et al., 1968). It is of considerable interest that goiter has not been reported for any of the groups on cassava-based diets since cassava is known to be goitrogenic (Delange et al., 1982).

There is no evidence of vitamin A deficiency among Amerindians, although this is a major health problem in many areas of the tropics. There are a number of good sources of carotenes in the diet, most notably peach palm (Bactris gasipaes).

\section{SUMMARY AND CONCLUSIONS}

In summary, the diets of Native Amazonians in tropical forest environments are based on cassava and plantains/bananas, with high quality protein coming from wild fauna. 
Wild plant foods do not appear to be very important in the diets of most groups, but their role has not been well studied and may be underestimated. The composition of Amerindian diets is known for only a few groups. It appears adequate in energy and protein, but the diets are high in bulk and low in caloric density. Dietary intake of household groups and adults appears adequate, and the nutritional status of adults is generally good. Children, however, are small for their age, and in some groups many would be classified as undernourished in the basis of weight-for-height, height-for-age, and/or clinical signs of undernutrition. It is likely that diet in combination with disease stress is responsible for the delayed growih and relatively poor nutritional status seen in some children.

This paper reviews and evaluates the available data on diet and nutritional status of Amerindians living in the tropical forests of Amazonia. The diets of most Amerindians are based on cassava and plantains/bananas, with high quality protein coming from fish, game and invertebrates. The composition of Amerindian diets is known for only a few groups. In these groups the dietary intake of households and adults appears to be adequate in energy and protein. However, the high bulk, low caloric density of the diets suggests that they are not concentrated enough for children. Anihropometric data is available for a number of groups. Adults are small in size, but nutritional status assessed in terms of weight-for-height is generally good. Children are small for their age, and in some groups more than 10\% would be classified as undernourished on the basis of weight-for-height, and/or clinical signs.

\section{REFERENCES}

AYRES, M. \& SALZANO, F. M. - Health status of Brazilian Kayapó Indians. Tropical and Geographical Medicine, 24: 178-185, 1972.

BEHRENS, C. A. - Shipibo ecology and economy: a mathematical approach to understanding human adaptation. Ph.D. Dissertation, University of California, Los Angeles, 1984. 
BÉNÉFICE, E.; BARRAL, H. \& ROMO-NUNEZ, Z. - Ecologie de la santé et de la nutrition en Amazonie équatorienne (Province de Napo). Bull. Soc. Path. Ex., 82: 531-543, 1989.

BERLIN, E. A. \& MARKELL, E. K. - An assessment of the nutritional and health status of an Aguaruna Jivar community, Amazonas, Peru. Ecology of Food and Nutrition, 6: 69-81, 1977.

BERLIN, O. B. \& BERLIN, E. A. - Etnobiologia, subsistencia y nutrición en una sociedad de la selva tropical: los Aguaruna Jivaro. Berkeley: University of California, 1977.

BLACK, F. L.; HIERHOLZERD, W. J.; BLACK, D. P.; LAMM, S. H.; LUCAS, L. - Nutritional status of Brazilian Kayapó Indians. Human Biology, 49: 139-153, 1977.

BOZA, F. \& BAUMGARTNER, J. - Estudio general, clinico y nutricional en tribus indigenas del Territorio Federal Amazonas de Venezuela. Archivos Venezolanos, 2: 144-225, 1962.

COIMBRA, C. E. A - Estudos de ecologia humana entre os Surui do Parque Indígena Aripuanã, Rondônia. Aspectos alimentares. Boletim do Museu Paraense Emilio Goeldi (Antropologia), 2: 57-58, 1985.

DELANGE, F.; BOURDOUX, P. \& ERMANS, A. M. - Summary and general conclusions. In: Nutritional Factors Involved in the Goitrogenic Action of Cassava (Delange, F.; Iteke, F. B. \& Ermans, A. M.), pp. 84-86, Ottawa, International Development Research Centre Monograph IDRC-184e, 1982.

DENEVAN, W. M. - The aboriginal population of Amazonia. In: The Native Population of the Americas in 1492 (Denevan, W. M., ed.), pp. 205-234, Madison, University of Wisconsin Press, 1976.

DRICOT-D`ANS, C. \& DRICOT, J. M. - Influence de l'acculturation sur la situation nutritionelle en Amazonie Peruvienne. Ann. Soc. Belge. Med. Trop., 58: 39-48, 1978.

DUFOUR, D. L. - Nutrition in the Northwest Amazon: household dietary intake and time-energy expenditure. In: Adaptive Responses of Native Amazonians (Hames, R. B. \& Vickers, W. T.), New York: Academic, 1983.

The time and energy expenditure of indigenous women horticulturalists in the Northwest Amazon. American Journal of Physical Anthropoloogy, 65: 37-46, 1984a.

Diet of Tukánoan Indians in the Northwest Amazon, Paper presented at the $83^{\text {rd }}$ Annual Meeting of the American Anthropological Association, Denver, 1984b.

Insects as food: A case study from the Northwest Amazon. American Anthropologist, 89: 383-397, 1987.

Cyanide content of cassava (Manihot esculenta, Euphorbiaceae) cultivars used by Tukánoan Indians in 
Northwest Amazonia. Economic Botany, 42: 255-266, 1988. Effectiveness of cassava detoxification techniques used by indigenous peoples in Nortwest Amazonia. Interciencia, 14: 86-91, 1989.

DUFOUR, D. L. n.d. - Anthropometric characteristics of Tukánoan Indians in the Colombian Vaupes region. Unpublished manuscript.

DUFOUR, D. L. \& ZARUCCHI, J. L. - Monopteryx angustifolia and Erisma Japura: Their use by indigenous people in the Northwest Amazon. Botanical Museum Leaflets of Harvard University, 27: 69-91, 1979.

ERMANS, A. M.; MBULAMOKO, M. N.; DELANGE, F. \& AHLUWALIA, R. - Role of cassava in the etiology of endemic goitre and cretinism. Ottawa, International Development Research Centre Monograph IDRC-136e, 1980.

EVANS, J. R.; MARTIN, J. \& MASCIE-TAYLOR, C. G. N. The effects of periodic deworming on the growth of pre-school children in Bangladesh. In: Proceedings of the XIII International Congress of Nutrition (Taylor, T. G. \& Jenkins, N. K.), London, John Libby, 1985.

EVELETH, P. B.; SAMZANO, F. M. \& DE LIMA, P. E. - Child growth and adult physique in Brazilian Xingu Indians. American Journal of Physical Anthropology, 41: 95-102, 1974.

FAGUNDES-NETO, U;; BARUZZI, R. G.; WEHBA, J.; SILVESTRINI, W. S.; MOARAIS, M. B.; CAINELLI, M. Observations of the Alto Xingu Indians (Central Brazil) with special reference to nutritional evaluation in children. American Journal of Clinical Nutrition, 34: 2229-2235, 1981.

FAO/WHO. - Energy and protein requirements. Technical Series no. 522. Geneva, World Health Organization, 1973.

FLOWERS, N. - Seasonal factors in subsistence, nutrition, and child growth in a Central Brazilian Indian community. In: Adaptive Responses of Native Amazonians (Hames, R. B. \& Vickers, W. T.), New York, Academic, 1983.

FREITAS, F. A. S.; OLIVEIRA, N. B. - Estudo sobre o estado nutritivo dos Xavántes. Revista Brasileiru de Medicina, 12: 565-567, 1955.

GLANVILLE, E. V. \& GEERDINK, R. A. - Skinfold thickness, body measurements and age changes in Tiriyó and Wayána Indians of Surinam. American Journal of Physical Anthropology, 32: 455-462, 1970.

GOMEZ, N. G. - Estudio médico-antropológico de la Amazonia Colombiana. Cali, Colombia, Universidad del Valle, 1968.

GOMEZ, G.; VALDIVIESO, M.; DE LA CUESTA, D. \& 
SALCEDO, T. S. - Effect of variety and plant age on the cyanide content of whole-root cassava chips and its reduction by sun-drying. Animal Feed Science and Technology, 11: $57-65,1984$.

GREGOR, T. - Anxious Pleasures: The Sexual Lives of an Amazonian People. Chicago, University of Chicago Press, 1985.

HERRERA, R.; JORDAN, C. G.; KLINGE, H. \& MEDINA, E. Amazon ecosystems: their structure and functioning with special emphasis on nutrients. Interciencia, 3: 223-230, 1978.

HIERNAUX, J. \& FROMENT, A. - The correlations between anthropometric and climatic variables in Sub-Saharan Africa: Revised estimates. Human Biology, 48: 757-767, 1976.

HILL, K. \& KAPLAN, H. - The Yora of Peru. Anthroquest, 41 : $1-9,1990$.

HODGE, L. \& DUFOUR, D. L. - Cross-sectional growth of young Shipibo children in eastern Peru. American Journal of Physical Anthropology, 84: 35-41, 1991.

HOLMES, R. - Estado nutricional en cuatro aldeas de la selva Amazónica - Venezuela: Un estudio de adaptación y aculturación. M. S. thesis, Instituto Venezolano de Investigaciones cientificas, Caracas, 1981.

HOLMES, R. - Non-dietary modifies of nutritional status in tropical forest populations. in Venezuela. Interciencia, 9: 386-390, 1984.

Nutritional status and cultural change in Venezuela's Amazon territory. In: Change in the Amazon Basin (Hemming, J., ed.), Manchester, University Manchester, 1985.

HUGH-JONES, S. - The Palm and the Pleiades: Initiation and Cosmology in Northwest Amazonia. Cambridge, Cambridge University Press, 1979.

JELLIFFE, D. B. - The assessment of nutritional status of the community. Geneva, WHO, 1966.

LARRICK, J. W.; YOST, J. A.; KAPLAN, J.; KING, G.; \& MAYHALL, J. - Patterns of health and disease among the Waorani Indians of Ecuador. Medical Anthropology, 3: 147 189, 1979.

LIZOT, J. - Population, risources and warfare among the Yanomámi. Man (NS), 12: 497-517, 1977.

MAYBURY-LEWIS, D. - Akwe-Shavante Society. New York, Oxford, 1967.

MCGREGOR, I. A. - Malaria: nutritional implications, Reviews of Infectious Disease, 4: 798-804, 1982.

NESTEL, B. \& MACINTYRE, R., Editors - Chronic cassava toxicity. Ottawa, International Development Research Centre 
Monograph IDRC-010e, 1973.

OSUNTOKUN, B. O. - Cassava diet, chronic cyanide intoxication and neuropathy in Nigerian Africans. World Review of Nutrition and Dietetics, 36: 141-173, 1981.

ORTIZ MORENO, M. E. - Encuesta nutritional y alimentaria de la Comisaria del Vaupes, Instituto Colombiano de Bienestar Familiar, Servicio Seccional de Salud del Vaupes, Bogota, 1981.

PRANCE, G. T. - The origin and evolution of the Amazon flora. Interciencia, 3: 207-222, 1978.

REVIERE, R.; COMAR, D.; COLONOMOS, M.; DESENNE, J. \& ROCHE, M. - Iodine deficiency without goiter in isolated Yanomama Indians: preliminary note. In: Biomedical Challenges Presented by the American Indian, pp. 120-123, Washington, D. C., Pan American Health Organization Scientific Publication № 165, 1968.

RIBEIRO, D. - Indigenous cultures and languages of Brazil. In: Indians of Brazil in the Twentieth Century (Hopper, J. H., ed.), pp. 69-76, Washington, D. C., Institute for Cross-Cultural Research, 1967.

ROSLING, H. - Cassava toxicity and food security. Uppsala, Sweden, Tryck kontakt, 1987.

ROSS, E. B. - The Achuara Jivaro: Cultural Adaptation in the Upper Amazon. Ph.D. Dissertation, Columbia University, New York, 1976.

SMOLE, W. J. - The Yanomama Indians. Austin, University Texas, 1986.

STINSON, S. - Variation in body size and shape among South American Indians. American Journal of Human Biology, 2: 37-51, 1990.

VICKERS, W. T. - Los Sionas y Secoyas. Quito, ABYA-YALA, 1989.

WATERLOW, C.; BUZINA, R.; KELLER, W.; LANE, J. M.; NICHAMAN, M.Z. \& TANNER, J. M. - The presentation and use of height and weight data for comparing the nutritional status of groups of children under the age of 10 years. Bulletin of the World Health Organization, 55: 489498, 1977.

WERNER, D. - Why do the Menkrangnoti trek? In: Adaptive Responses of Native Amazonians (Hames, R. B. \& Vickers, W. T.), New York, Academic, 1983.

WHEELER, E. F. - Nutritional status of savanna peoples. In: Human Ecology in Savanna Environments (Harris, D. R., ed.), New York, Academic, 1980.

WHO - Working Group. Use and interpretation of anthropometric indicators of nutritional status. Bulletin of the World Health Organization, 64: 929-941, 1986. 